\title{
Geopolitical Entities, Names, and Codes Terminology
}

National Cancer Institute

\section{Source}

National Cancer Institute. Geopolitical Entities, Names, and Codes Terminology. NCI

Thesaurus. Code C124085.

Codes for the representation of names of countries and their subdivisions that have been approved by the US Board on Geographic Names. 